\title{
Institutional fundamentals of authorized supply chains formation
}

\author{
Aleksandr V. Parfenov \\ Department of supply chains logistics \\ and management \\ Saint Petersburg state University of \\ economics \\ Saint Petersburg, Russia \\ parfenof@mail.ru
}

\author{
Tkach V. Vladimirovich \\ Department of commerce and \\ merchandizing \\ Saint Petersburg state University of \\ economics \\ Saint Petersburg, Russia \\ vvt@unecon.ru
}

\author{
Yuan Xiaohui \\ Department of supply chains logistics \\ and management \\ Saint Petersburg state University of \\ economics \\ Saint Petersburg, Russia \\ yuanxiaohui@mail.ru
}

\begin{abstract}
This paper is addressing the issues regarding formation of authorized supply chains in international trade with reference to the World Customs Organization (WCO) standards and specific aspects of customs administration. The paper is evaluating the WCO imperatives and modern information technologies used in the sphere of customs risks management. It is defining the weak points of international China to Russia supply chains. It is substantiating the necessity to make analytical assessment of evolution of institute of authorized economic operators in China and in the RF. The paper brings to light particular features of institute of authorized economic operators in China and defines directions of its further development. It is evaluating specificity of evolution of institute of authorized economic operators in the RF under the conditions of customs regulations harmonization in Eurasian economic Union (EAEU). It was noted that innovation of the EAEU customs' Code consists in possibility to issue three types of certificates which are verifying party's incorporating into the Register of authorized economic operators and (2) differentiation of special simplifications depending on the type of a certificate.
\end{abstract}

Key words - China, Russia, international trade, international supply chains, customs administration, customs risks, authorized economic operator, authorized supply chains

\section{INTRODUCTION}

Increasingly growing trade cooperation between China and Russia makes transition form one-off deals between the enterprises to integrated interaction within international supply chains a crucial task. However, the problem associated with customs administration in the international trade comes into the spotlight against the background of these positive trends. Probably, this problem may be solved due to the fact that in both countries institutional measures intended to establish "authorized economic operator" (AEO) category into legal and business practice were taken. Interaction between the foreign economic activities FEA participants and the AEO is not only shifting "gravity center" of customs administration on such operator but is also decreasing logistics risks in international supply chains. The WCO Framework of Standards to Secure and Facilitate Global Trade envisages [1] that customs services of the WCO member states must use modern information technologies to reveal increased-risk cargoes and transportation facilities at an earliest possible stage of international goods supply chain - in goods shipment port or even in goods production and distribution areas. At that, AEO operators belong to low-risk category of international supply chains participants and, as a consequence, they receive considerable benefits due to expeditious customs processing of goods. In case AEO operators are reciprocally recognized by customs offices of importing and exporting parties it is expected that international supply chains will obtain the status of authorized goods supply chains. Despite the fact that the RF and China have been for a long time using the institute of AEO and modern information technologies in risks management there is still no agreement between them regarding reciprocal recognition of AEO status. Conspicuous is the fact that main logistics operators participating in China-Russia supply chains like JSC Russian Railways and FSUE Russian Post are still without the status of AEO although they are fully complying with all requirements put forward to them including safety standards. All this makes research of institutional features of authorized supply chains formation within the framework of ChinaRussia international trade under the condition of customs operations digitization a crucial task.

\section{MATERIALS AND METHODS}

Poor efficiency of customs administration is an acute problem of Russian economy. Solving of this problem is the prerogative right of the state. However, it should be preceded by scientific research conducted in line with the RF legislation and with account to specific features of the EAEU customs regulations. This circumstance is objectively shifting the field of research to the side of Russian specialists. Analysis of scientific research papers shows that such research are focusing mainly on two basic directions: 1) ascertaining of new amendments in customs legislations; 2) analysis of customs practices with reference to goodsrelated and country-related features of. Besides, focus in such publications is made on "risk-free" customs processing regardless of attempts to find optimized combination between inter-company cooperation maintained within international supply chains and mechanisms of customs processing. Solution of this problem demands understanding of institutional features of such regulating and of customs administration evolution directions forecasting as well. The latter issue is given sporadic attention to (exclusion publication [3]). This issue within international supply chains under the condition of globalization characterized by the total expansion of the WCO standards and digital risks management technologies is becoming crucial. Positive dynamics of goods exchange between China and Russia (China being the basic trade partner of Russia) adds acuteness thereto [4]. This dynamics facilitates logistics convergence of the RF and Chinese national economies, 
making transition of both countries to higher level of customs relations a crucial issue [5]. Implementation of this condition is to the great extent connected with reciprocal recognition of their AEO operators' status and employment of harmonized digital technologies in customs administration. Chinese and Russian FEA participants must be ready to such scenario. This provision stipulates the necessity to perform analytical assessment of evolution of the AEO institute in Russia and China proceeding from these countries' customs legislation and international standards of customs operations digitization.

\section{RESULTS}

The institute of AEO within the framework of international law was for the first time adopted by the Framework of Standards to Secure and Facilitate Global Trade in 2005 at annual WCO Council session [1]. 2007 year version of these standards was supplemented by provisions and requirements put forward to customs administrations and the AEO which were originally developed as a standalone document. In 2010 the WCO issued a document represented as a Complex of customs actions taken in order to ensure security of customs operations and facilitate international trade which integrated entire documents supporting these standards implementation [1].

The AEO satisfying the criteria established by national customs services are entitled to employ simplified and fasttrack goods release procedures, for example, through the decrease of proportion of goods under inspection in case of minimum required information submission. This, in turn, allows to reduce costs for entire participants of international supply chain and to accelerate customs processing of goods. Framework of standards assumes that customs services of the WCO member states must come to a reciprocal recognition of the AEO status in order to improve goods supply chain security and harmonize customs procedures [1]. In case of reciprocal recognition of the AEO status it is expected that international supply chains where target companies are represented by the AEO from the WCO member states will acquire the status of "authorized goods supply chains".

China entered the WCO Framework of Standards to Secure and Facilitate Global Trade in June 2005 and since that time implemented a number of institutional measures to create and improve national authorized economic operators system. Basic difference of this system from the US AEOs system is that it was created on the basis of enterprise credit rating assessment. Where an enterprise commits essential breach of law it is expected that level of its credit rating will decrease and the state will undertake more strict customs control measures in respect thereof [6]. In 2008 Chine put in force "Administrative measures to classify national customs enterprises" according to which all FEA participants and customs brokers were differentiated into five categories AA, A, B, C and D. Out of them only three categories: AA high level, A - standard level and B - normal level (trustworthy) could be referred to the AEO system. Enterprises belonging to categories $\mathrm{C}$ and $\mathrm{D}$ had to be subjected to credit rating re-testing so as to be further referred either to category B or to "bad-faith enterprise" category. In 2014 China put into force "Temporary measures aiming to execute Chinese customs enterprises' credits management", classification into five categories (AA, A, B, C, D) was cancelled and differentiation of entire Chinese FEA participants into five groups was standardized as follows: senior certification enterprise, general certification enterprise, general credit enterprise and badfaith enterprise. This document distinctively stipulates that only senior certification enterprises could acquire the status of AEO and, accordingly, the right to use customs preferences in the company economic activities. It is also establishing 18 certified corporate standards including inhouse audit, financial compliance, conformity standards and trade security. In 2018 China put into force new document entitled "Measures intended to manage the credits of Chinese customs enterprises" [7] according to which customs authorities are obliged to classify FEA participants, with reference to their credit status, into certified enterprises, enterprises of general financing and insolvent enterprises. At that, only certified enterprises may be referred to the category of certified operators (AEOs) of Chinese customs and they can be classified into two types: advanced certified enterprises and general certified enterprises. At the same time, "certified operator (AEO)" is understood as an enterprise which in any way participates in international goods exchange, complies with provisions stipulated herein and observes enterprise's certified Customs standards and which successfully passed customs certification [7]. In 2019 China achieved reciprocal recognition of "certified operator" (AEO) status with 36 countries and regions including Singapore, South Korea, Hong Kong, European Union, Switzerland, New Zealand, Israel, Australia, Japan and today is delivering about $45 \%$ of total Chinese export to the said countries and areas [8]. China is conducting consultations regarding reciprocal recognition of AEO status with Russia, Mongolia, Kazakhstan, Belarus, Malaysia, Iran, Mexico and Serbia. At the same time, progress of forming the institute of AEO in $\mathrm{RF}$ is rather poor [9].

Institute of AEO was for the first time standardized in the RF in 2010 by the Customs Code of the Customs Union (CU) $[11,12]$. According to [12], the AEO status may be assigned to legal entity (LE) registered in line with applicable RF legislation, performing importation of goods to the RF for use in production and other business activities, exportation of goods from the RF and included in the AEO Register.

Further development of the AEO institute continued upon enforcement of the EAEU Customs Code and respective Federal Law $[13,14]$. According to the EAEU Customs Code [13], the AEO is a LE established in line with member state's legislation and included in the AEO Register in accordance and with observance of conditions set forth by [13].

Innovation proposed by the EAEU Customs' Code consists in (1) possibility to issue three types of certificates which are verifying party's incorporating in the AEO Register and (2) differentiation of special simplifications depending on the type of certificate. Besides, customs legislation of member states is for the first time not only listing special simplifications but is also giving their legal interpretation - they are presented as (i) specific conditions of conducting particular customs operations and customs 
control and (ii) other specific conditions of applying the provisions of the EAEU Customs Code depending on the type of the AEO certificate [13].

Table 1 presents logistics interpretation and substantial characteristic of these simplifications which may be used by AEOs of the member states which obtained certificate of $1 \mathrm{st}$ or 2 nd type. At that, it is necessary to take into account that, according to [13], a certificate which is verifying inclusion into 3rd type register entitles the AEO to use all special simplifications which are provided by certificates of types 1 and 2 .

TABLE I. LOGISTICS INTERPRETATION OF SPECIAL SIMPLIFICATIONS PROVIDED TO AEO

\begin{tabular}{|c|c|c|}
\hline \multirow[t]{2}{*}{ Operations } & \multicolumn{2}{|c|}{ Certificate } \\
\hline & type 1 & type 2 \\
\hline $\begin{array}{l}\text { Transportation } \\
\text { of goods }\end{array}$ & 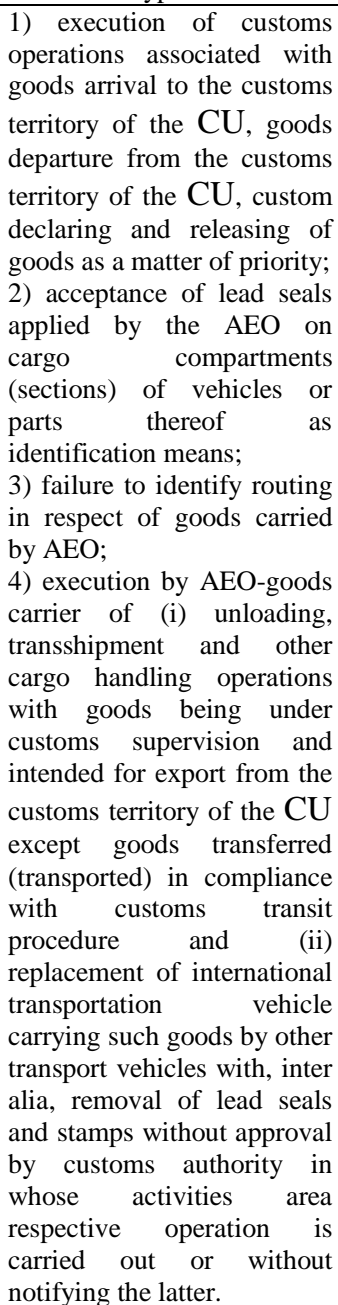 & 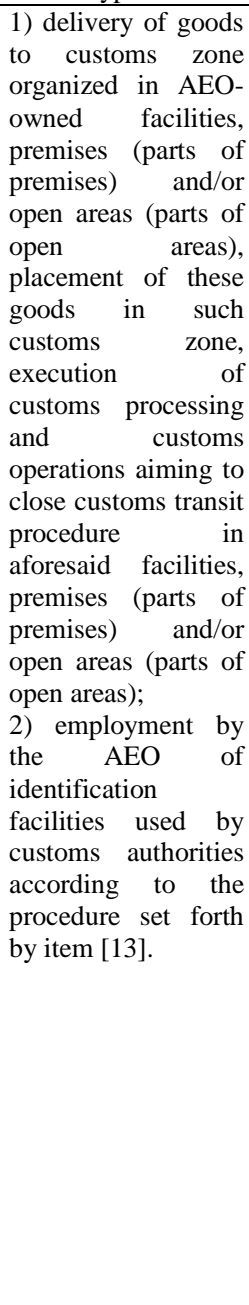 \\
\hline $\begin{array}{l}\text { Temporary } \\
\text { storage } \\
\text { of goods }\end{array}$ & & $\begin{array}{l}\text { 1) temporary storage } \\
\text { of goods in AEO- } \\
\text { owned facilities, } \\
\text { premises (parts of } \\
\text { premises) and/or } \\
\text { open areas (parts of } \\
\text { open areas); } \\
\text { 2) temporary storage } \\
\text { (in AEO-owned } \\
\text { facilities, premises } \\
\text { (parts of premises) } \\
\text { and/or open areas } \\
\text { (parts of open } \\
\text { areas)) of goods } \\
\text { owned by entities }\end{array}$ \\
\hline
\end{tabular}

\begin{tabular}{|c|c|c|}
\hline & & $\begin{array}{l}\text { having no AEO } \\
\text { status where it is } \\
\text { stipulated } \\
\text { applicable } \\
\text { legislation of the } \\
\text { member states. }\end{array}$ \\
\hline $\begin{array}{l}\text { Financial } \\
\text { support }\end{array}$ & $\begin{array}{l}\text { 1) failure to provide security } \\
\text { of fulfilling commitments } \\
\text { regarding payment of } \\
\text { custom duties, taxes, special, } \\
\text { anti-damping and } \\
\text { compensation duties at the } \\
\text { stage of AEO-declared } \\
\text { goods releasing, with } \\
\text { peculiarities specified in } \\
\text { [13]; foriture to provide security } \\
\text { 2) failurits } \\
\text { of fulfilling commitments } \\
\text { regarding payment of } \\
\text { custom duties, taxes, special, } \\
\text { anti-damping and } \\
\text { compensation duties if } \\
\text { requirement to fulfill such } \\
\text { commitments is set forth by } \\
\text { [13] where goods have been } \\
\text { put under customs transit } \\
\text { procedure. }\end{array}$ & $\begin{array}{l}\text { 1) failure to provide } \\
\text { security of fulfilling } \\
\text { commitments } \\
\text { regarding payment } \\
\text { of custom duties, } \\
\text { taxes, special, anti- } \\
\text { damping and } \\
\text { compensation duties } \\
\text { at the stage of AEO- } \\
\text { declared goods } \\
\text { releasing, with } \\
\text { peculiarities } \\
\text { specified in [13]; } \\
\text { 2) failure to provide } \\
\text { security of fulfilling } \\
\text { commitments } \\
\text { regarding payment } \\
\text { of import customs } \\
\text { duties where } \\
\text { payment of import } \\
\text { customs duties is } \\
\text { deferred according } \\
\text { to [13] if the AEO } \\
\text { acts in capacity of } \\
\text { goods declarant. }\end{array}$ \\
\hline $\begin{array}{l}\text { Customs } \\
\text { processing }\end{array}$ & $\begin{array}{l}\text { 1) releasing of goods prior } \\
\text { to declaration submission } \\
\text { according to [13]; } \\
\text { 2) execution of customs } \\
\text { control where it is assigned } \\
\text { in the form of customs } \\
\text { examination which should } \\
\text { be done as a matter of } \\
\text { priority; } \\
\text { 3) priority-oriented } \\
\text { participating in pilot projects } \\
\text { and experiments (intended to } \\
\text { reduce time and optimize the } \\
\text { procedure of customs } \\
\text { operations execution) } \\
\text { organized by customs } \\
\text { authorities. }\end{array}$ & $\begin{array}{l}\text { 1) releasing of } \\
\text { goods prior to } \\
\text { declaration } \\
\text { submission } \\
\text { according to [13]; } \\
\text { 2) execution of } \\
\text { customs control } \\
\text { where it is assigned } \\
\text { in the form of } \\
\text { customs examination } \\
\text { which should be } \\
\text { done as a matter of } \\
\text { priority; } \\
\text { 3) execution of } \\
\text { customs control in } \\
\text { AEO-owned premises } \\
\text { facilities, prem } \\
\text { (parts of premises) } \\
\text { and/or open areas } \\
\text { (parts of open } \\
\text { areas); ex of ar of } \\
\text { 4) execution of } \\
\text { customs operations } \\
\text { associated with } \\
\text { customs declaring } \\
\text { and releasing of } \\
\text { goods with customs } \\
\text { authority other than } \\
\text { custom authority in } \\
\text { whose activities area } \\
\text { these goods are } \\
\text { placed on condition } \\
\text { that such customs } \\
\text { authorities are } \\
\text { located in member } \\
\text { state territory. }\end{array}$ \\
\hline
\end{tabular}

Conditions of LE inclusion in the AEO Register with issuing of the 1st, 2nd and 3rd type certificate are set forth by [13] and may be differentiated into general conditions of inclusion in the Register and specific conditions which are foreseen for the AEO holding particular type of certificate (Table 2). Besides, [13] defines minimum quantitative 
and/or cost-related indices required for the AEO status acquisition (Table 3) and cases and amounts of the AEO commitments fulfillment security.

TABLE II. CONDITIONS OF LEGAL ENTITY INCLUSION IN AEO REGISTER

\begin{tabular}{|c|c|c|c|}
\hline \multirow[t]{2}{*}{ Conditions of inclusion in AEO Register } & \multicolumn{3}{|c|}{$\begin{array}{c}\text { Type of } \\
\text { certificate }\end{array}$} \\
\hline & $\mathrm{I}$ & II & III \\
\hline $\begin{array}{l}\text { 1. LE AEO performed in the sphere of customs } \\
\text { services in capacity of customs representative, owner } \\
\text { of temporary storage facility, customs warehouse } \\
\text { performed during minimum } 3 \text { years or performing } \\
\text { customs carrier activities during minimum } 2 \text { years. }\end{array}$ & + & + & + \\
\hline 2. AEO commitments fulfillment security. & + & - & - \\
\hline $\begin{array}{l}\text { 3. Absence (in entire member states) of overdue } \\
\text { commitments regarding special, anti-damping, } \\
\text { compensation duties, fines and percents. }\end{array}$ & + & + & + \\
\hline $\begin{array}{l}\text { 4. Absence (in member state of the LE registration) of } \\
\text { indebtedness (arrears) associated with member states' } \\
\text { tax legislation. }\end{array}$ & + & + & + \\
\hline $\begin{array}{l}5 . \quad \text { Absence of facts of holding this LE } \\
\text { administratively liable (in entire member states during } \\
1 \text { year prior to customs authority's registration of the } \\
\text { case) for certain breach of the law. }\end{array}$ & + & + & + \\
\hline $\begin{array}{l}\text { 6. Absence of facts evidencing that in entire member } \\
\text { states (i) any physical persons-residents thereof } \\
\text { holding the status of this LE shareholders with } 10 \% \\
\text { of shares and more, (ii) its founders (participants), } \\
\text { managers and chief accountants were brought to } \\
\text { criminal responsibility for certain breach of the law. }\end{array}$ & + & + & + \\
\hline $\begin{array}{l}\text { 7. Availability of goods record keeping system } \\
\text { satisfying requirements set forth by applicable } \\
\text { legislation of member states and enabling the user to } \\
\text { compare information provided to customs authorities } \\
\text { in the course of customs processing which includes } \\
\text { data concerning economic operations and ensures } \\
\text { access (including remote access) to such data for the } \\
\text { customs authorities. }\end{array}$ & + & + & + \\
\hline $\begin{array}{l}\text { 8. Compliance of this LE financial stability with } \\
\text { values established by the Commission and by member } \\
\text { states' legislations. }\end{array}$ & - & + & + \\
\hline $\begin{array}{l}\text { 9. Requirement for facilities, premises (parts of } \\
\text { premises) and/or open areas (parts of open areas)) } \\
\text { intended for temporary goods storage to be in the } \\
\text { status of ownership, operational control or leasing. }\end{array}$ & - & + & + \\
\hline $\begin{array}{l}\text { 10. Observance of requirements put forward towards } \\
\text { (i) facilities, premises (parts of premises) and/or open } \\
\text { areas (parts of open areas) on whose territory } \\
\text { temporary goods storage, completion of customs } \\
\text { transit procedure will be organized and/or customs } \\
\text { control will be carried out, (ii) to transport vehicles } \\
\text { and (iii) LE employees. }\end{array}$ & - & + & + \\
\hline $\begin{array}{l}\text { 11. LE is included in the AEO Register with the } 1 \text { st or } \\
2 \text { nd type certificate issuing within minimum } 2 \text { years } \\
\text { to the date of application registration by customs } \\
\text { authority. }\end{array}$ & - & - & + \\
\hline
\end{tabular}

TABLE III. QUANTITATIVE AND COST-RELATED INDICES OF AEO STATUS ACQUISITION

\begin{tabular}{|c|c|c|}
\hline Types of activities & Quantitative indices & Cost-related indices \\
\hline $\begin{array}{l}\text { Persons } \\
\text { involved in FEA }\end{array}$ & $\begin{array}{l}\text { Quantity of goods } \\
\text { declarations furnished } \\
\text { annually in quantities } \\
\text { established r by } \\
\text { applicable legislation } \\
\text { of member states, } \\
\text { however, not less than } \\
10 .\end{array}$ & $\begin{array}{l}\text { Total cost of goods } \\
\text { carried across the } \\
\text { customs border of the } \\
\text { CU in each year reaches } \\
\text { the amount established } \\
\text { by applicable legislation } \\
\text { of member states, } \\
\text { however not less than }\end{array}$ \\
\hline
\end{tabular}

\begin{tabular}{|c|c|c|}
\hline & & $\begin{array}{l}\text { amount equivalent to } 500 \\
\text { thousand Euro. }\end{array}$ \\
\hline $\begin{array}{l}\text { Customs } \\
\text { representatives }\end{array}$ & $\begin{array}{l}\text { In each year quantity } \\
\text { of goods declarations } \\
\text { furnished annually in } \\
\text { quantities established } \\
\text { by applicable } \\
\text { legislation of member } \\
\text { states, however, not } \\
\text { less than } 200 \text {. }\end{array}$ & $\begin{array}{l}\text { Total cost of goods } \\
\text { declared in customs } \\
\text { declarations submitted by } \\
\text { them in each year is } \\
\text { reaching the amount } \\
\text { established by applicable } \\
\text { legislation of member } \\
\text { states, however, not less } \\
\text { than amount equivalent } \\
\text { to } 500 \text { thousand Euro. }\end{array}$ \\
\hline $\begin{array}{lr}\text { Owners } & \text { of } \\
\text { temporary } & \text { storage } \\
\text { areas, customs } & \text { customses }\end{array}$ & & $\begin{array}{l}\text { Performed storage of } \\
\text { goods whose total cost in } \\
\text { each year reaches the } \\
\text { amount established by } \\
\text { applicable legislation of } \\
\text { member states, however, } \\
\text { not less than amount } \\
\text { equivalent to } 500 \\
\text { thousand Euro. }\end{array}$ \\
\hline $\begin{array}{l}\text { Customs } \\
\text { carriers }\end{array}$ & $\begin{array}{lr}\text { In each year } & \text { minimum } \\
250 & \text { customs } \\
\text { declarations } & \text { were } \\
\text { submitted. } & \\
\end{array}$ & \\
\hline $\begin{array}{l}\text { International cargo } \\
\text { carriers }\end{array}$ & $\begin{array}{lr}\text { In each year } & \text { minimum } \\
250 & \text { customs } \\
\text { declarations } & \text { were } \\
\text { submitted. } & \\
\end{array}$ & \\
\hline
\end{tabular}

As set forth by [13], legislation of the member states regarding customs regulation may specify additional conditions of LE inclusion in the AEO Register. In Russia additional conditions of a LE inclusion in the AEO Register are set forth by [14]:

According to [13], such operator, beginning from the date of enforcement of the certificate verifying LE inclusion in the AEO Register, belongs to low risk category and, therefore, simplified accelerated customs processing procedure may be applied thereto

\section{DISCUSSION}

Wide development of the RF market by Chinese enterprises demands from them more active logistics position. It must foresee establishment of international supply chains under the authority thereof and organization of well coordinated contract-based management with the use of ISO standards $[15,16]$. At the same time, for the time being is it quixotic to expect total transition, in Chinese enterprises' attitude to FEA, from one-off deal to far-reaching transformations in the sphere of customs administration in China and the RF. However, analysis of evolution of customs regulation in these countries shows that breakthrough may be anticipated in the coming years. We dovetail such breakthrough with further development of the AEO institute in these countries, reciprocal AEO institute recognition in China and the RF and formation of authorized supply chains. This situation is, in our opinion, makes requirement for Chinese enterprises to establish economic relations with active and potential AEOs a crucial issue.

\section{CONCLUSION}

Taking the aforesaid into account, we can specify the following ways to establish the chains of Chinese goods supply to Russia with a purpose to minimize overall logistics costs and to decrease the customs risks: 
- obtaining (by the target company) of certificate verifying inclusion in the AEO Register of type 2 entitling the holder to use special simplifications regarding temporary storage and customs declaring of imported goods in AEOowned facilities, premises and/or open areas;

- selection (in capacity of target company within Chinese goods supply chains) of national and/or regional distributors satisfying the established requirements regarding absolute and relative indices of financial stability;

- selection (in capacity of the target company within the chains of auxiliary logistic services supply) of integrated providers capable to organize international transportation, temporary storage, customs declaring and delivery of Chinese goods up to distribution centers of retail networks and/or non-networked shops;

- obtaining of "authorized goods supply chain" status through (i) execution of the RF-China agreement regarding reciprocal recognition of the AEO institute or (ii) involvement of Russian AEO and certified Chinese operator in capacity of international supply chain participants.

\section{REFERENCES}

[1] Framework of Standards to Secure and Facilitate Global Trade [Electronic source] // World Customs Organization. - Access mode: http://www.wcoomd.org/

[2] LPI Global Rankings 2018 [Electronic source]. - Access mode https://lpi.worldbank.org/international/global.

[3] Parfenov A.V., Shapovalova I.M. Evolution of customs procedures in Russia: from customs administration to customs logistics / A.V. Parfenov, I.M. Shapovalova. - Saint Petersburg: Publishing house of Saint Petersburg state University of economics, 2016. - p. 161.

[4] Federal State Statistics Service [Electronic source]. - Access mode: http://www.gks.ru.
[5] Rybakov, D.S. Total cost optimisation model for logistics systems of trading companies (2017) 27 (3), pp. 318-342.

[6] Ismagilova, L.A., Gileva, T.A., Galimova, M.P., Glukhov, V.V. Digital business model and smart economy sectoral development trajectories substantiation (2017) 10531 LNCS, pp. 13-28.

[7] Order of China's General Directorate of Customs No. $237 \mathrm{dd}$ 03.03.2018 г. [Electronic source]. - Access mode: http://www.customs.gov.cn/customs/302249/302266/302267/1471687 /index.html.

[8] China and 36 countries and regions will reciprocally recognize institute of customs authorized economic operator [Electronic source]. Access mode: http://www.xinhuanet.com/201901/15/c_1123994907.htm

[9] Zaychenko, I., Smirnova, A., Borremans, A. Digital transformation: The case of the application of drones in construction (2018) 193, 05066..

[10] RF Customs Code: RF Federal Law dated 28.05.2003 No. 61-FZ.

[11] Customs Code of the Customs Union (rev. dated 08.05.2015) (attachment to Agreement on Customs Code of the Customs Union adopted by Solution of Interstate Council of the Eurasian Economic Community on head-of-state level dated 27.11.2009 No. 17).

[12] Concerning customs regulation in RF: RF Federal Law dated 27.11.2010 No.311-FZ

[13] Customs Code of the Eurasian Economic Community (attachment No 1 to the Agreement on Customs Code of the Eurasian Economic Community adopted on the Eurasian Economic Community head-ofstate level on 11.04.2017).

[14] Concerning customs regulation in RF and amendments in particular the RF legal acts: RF Federal Law dated 03.08.2018 No.289-FZ.

[15] Kubasova, T., Tkach, V., Tsvigun, I. Priorities of the logistics risks management in the resource support of construction projects. MATEC Web of Conferences 212, 08010 (2018).

[16] ISO 28002. Security management systems for the supply chain Development of resilience in the supply chain - Requirements with guidance for use. 